\title{
Pigmented villonodular synovitis in pediatric population: review of literature and a case report
}

\author{
Mohsen Karami*, Mehryar Soleimani and Reza Shiari
}

\begin{abstract}
Background: Pigmented villonodular synovitis (PVNS) is a rare proliferative process in children that mostly affects the knee joint.

Case Presentation: The study follows the case of a 3-year-old boy presenting recurrent patellar dislocation and PVNS. Due to symptoms such as chronic arthritis, he had been taking prednisolone and methotrexate for 6 months before receiving a definitive diagnosis. After a period of showing no improvements from his treatment, he was referred to our center and was diagnosed with local PVNS using magnetic resonance imaging (MRI). The patient was treated for his patellar dislocation by way of open synovectomy, lateral retinacular release, and a proximal realignment procedure, with no recurrence after a 24-month follow-up.

Conclusion: PVNS may appear with symptoms resembling juvenile idiopathic arthritis, thus the disease should be considered in differential diagnosis of any inflammatory arthritis in children. PVNS may also cause mechanical symptoms such as patellar dislocation. In addition to synovectomy, a realignment procedure can be a useful method of treatment.
\end{abstract}

Keywords: Juvenile idiopathic arthritis, Patellar dislocation, Pigmented villonodular synovitis

\section{Background}

Pigmented villonodular synovitis (PVNS) is a rare proliferative process that affects the synovial joint, tendon sheaths, and bursa membranes [1]. The estimated incidence of PVNS is around 1.8 cases per million people in a population [1]. PVNS is usually found in adults aged 20-50 years, but it may also be found in children [2-4].

The youngest patient reported with PVNS was 12 months old [5]. Knee involvement is common in pediatric PVNS, although other affected areas have been reported, such as the foot and ankle, elbow, hip, sacroiliac joint, and multiple joint involvements [3, 5-32]. Some authors have determined that there is no sex predilection in PVNS, while other reports have shown a male or female predominance $[1,2,33]$.

The etiology of PVNS is unknown, but chronic inflammation, a tumor-like disorder with chromosomal

* Correspondence: mnkarami@gmail.com

Mofid Children Hospital, Shahid Beheshti University of Medical Sciences, Shariati Ave., Tehran 15514-15468, Iran aberrations that cause hemorrhagic tendencies, as well as genetic factors, have been proposed as potential causes $[2,3]$. Trauma and rheumatoid arthritis association have also been considered [14, 15, 33].

The following study reports on a 3-year-old boy with a 4-month-long history of pain and swelling in the right knee. The patient was initially treated for juvenile idiopathic arthritis (JIA) and growth retardation.

\section{Case Presentation}

This study follows the case of a 3-year-old boy with a 4-month-long history of pain and swelling in the right knee and no history of trauma. The patient had been taking prednisolone and methotrexate for a period of 6 months in response to signs and symptoms very similar to juvenile idiopathic arthritis (JIA). Previously, he had also received a yearlong growth hormone treatment, for which the medical reason is unknown. He had no familial history of rheumatological conditions.

A physical examination of the patient revealed swelling and a limited range of motion in the knee. It was 
clinically evident that the patella had been dislocated. The results of laboratory tests did not suggest that the patient suffered from JIA. Radiography images depicted soft tissue swelling around the knee joint. An MRI showed a large signal mass of synovium posterior to the lateral patellar facet, which caused lateral dislocation of the patella (Fig. 1).

The chosen method of treatment for the patient was surgery, consisting of an open excisional biopsy and a proximal realignment procedure (vastus medialis obliquus advancement) through medial parapatellar incision. A histologic examination of the tissue exposed hyperplasia of the synovium, foamy macrophage, spindle cells, multinucleated giant cells and a considerable amount of hemosiderin deposits, all of which supported the diagnosis of PVNS (Fig. 2).

After the open surgical synovectomy and 3 months of physiotherapy, the swelling of the knee lessened and the range of motion in the knee returned to normal. The patient was followed for 24 months without any signs of recurrence.

\section{Discussion}

This study reviews and summarizes 29 articles, published between 1975 and 2016, in which 42 cases of pediatric PVNS were reported [3, 5-32] (Table 1). Because of the impossibility to retrieve pediatric data, the articles representing mixed adult and pediatric cases were excluded from the review [34]. The mean age of the reported cases was 8.9 years. Sixty-two percent $(n=26)$ was female and $38 \%(n=16)$ was male. PVNS affected only one joint in all but 6 cases, and the main localization was the knee joint $(n=23,64 \%)$.

Approximately $81 \%(n=34)$ of patients presented joint pain and swelling. This entity may have been misdiagnosed with other causes of arthritis such as rheumatoid arthritis, hemophilic arthropathy, tuberculosis, and neoplastic processes $[3,15]$.

A localized intra-articular form of PVNS that causes mechanical symptoms, such as anterior knee pain, meniscal injury, and patellar dislocation has been reported in adult PVNS [35-39]. Mechanical symptoms are extremely rare in pediatric cases of PVNS [3, 5-32]. Recurrent patellar dislocation is a rare presentation of PVNS that was previously only reported in adult cases [38]. This study presents a 3-year-old boy with patellar dislocation caused by PVNS, an unusual demonstration of PVNS at an unusual age. To the best of our knowledge, this is the first report of patellar dislocation in pediatric PVNS.

Joint aspiration fluid in PVNS is usually serosanguinous and, without a history of trauma, can be nearly diagnostic [2]. Initial stages of radiography may show an increasing density or radiolucent defect with a thin sclerotic rim [2,3]. Only $33 \%$ of reported cases of pediatric PVNS produced positive findings on the initial X-ray [3]. In the present case, radiography images showed nothing more than swelling of the soft tissue. CT-scans are useful in determining the severity of bone loss in large joints such as the hip and knee. Medium-contrast enhanced CT-scans may also be worthwhile in detecting recurrent lesions [2]. The most effective screening method for diagnosis of PVNS is the MRI. MRIs can reveal scattered low-signal intensity areas in the synovial membrane, representing hemosiderin deposits on T2weighted images, and dotted areas of low-signal intensity, representing fibrous components of the lesion on T1-weighted images [1-3] (Fig. 1).

There is not a standard method of treatment for PVNS, especially in pediatric patients [1-3]. The aim of treatment for PVNS is to remove all abnormal tissue in order to relieve pain, lower the risk of joint destruction,

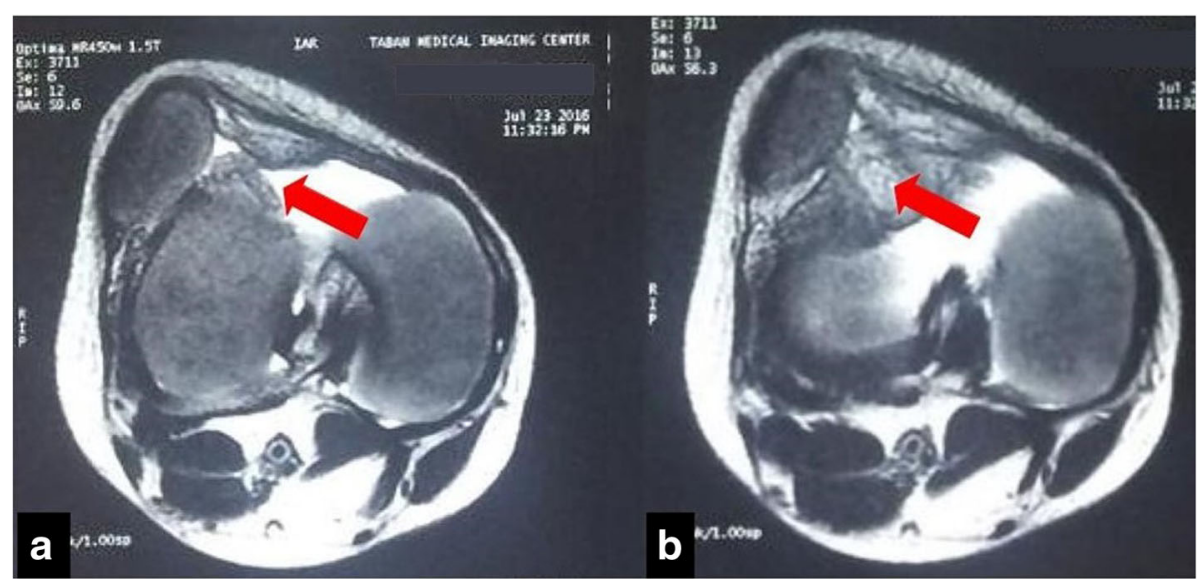

Fig. 1 MR image. a Arrow showes synovial proliferation on T2-Weighted image. Note patellar dislocation and joint effusion. b Arrow indicates scattered low-signal intensity areas in the synovial membrane, representing hemosiderin deposits on T2-weighted images 


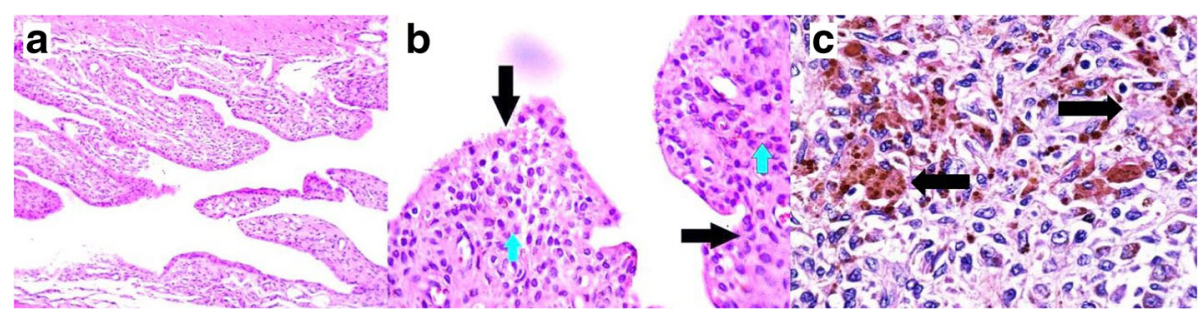

Fig. 2 Microscopic section of the synovial biopsy, Pigmented Villonodular Synovitis, a. Villous and nodular configuration. Note the hypertrophied synovium. ( $\times 4$ and $\times 10$, Hematoxylin-Eosin), b. Hypertrophied synovium (black arrows) and histiocytes, Hemosiderin-laden macrophages and osteoclastlike giant cells (blue arrowheads) are visible. ( $\times 40$, Hematoxylin-Eosin), $\mathbf{c}$. This section shows admixture of hemosiderin-laden and lipid-laden macrophages

and avoid local recurrence. The localized form of PVNS tends to be episodic and result in a good prognosis, while the diffuse form tends to progress gradually and recur more frequently $[1,4,33]$. Though there are several therapeutic solutions, the most common treatment is surgery [3]. Open or arthroscopic subtotal synovectomy is the most widely accepted surgery [1-3]. Some authors prefer arthroscopy to treat the localized form because this method results in less morbidity and a similar outcome as open surgery [1]. Some others

Table 1 Clinical presentations reported in literatures

\begin{tabular}{|c|c|c|c|c|c|c|c|}
\hline Clinical presentation & Number of patients & Age (years) & Sex & Treatment $\left(\mathrm{OS}^{\mathrm{a}} / \mathrm{AS}^{\mathrm{b}}\right)$ & Follow up & Recurrence & Authors \\
\hline $\begin{array}{l}\text { Knee pain } \\
\text { and swelling }\end{array}$ & 21 & 1-15 (mean 9.1) & $10 \mathrm{M}^{c}, 11 \mathrm{~F}^{\mathrm{d}}$ & $\begin{array}{l}12 \mathrm{OS}, 7 \mathrm{AS}, \\
1 \mathrm{OS}+\mathrm{AS}, \\
1 \text { injection }\end{array}$ & 5 month-2 years & None & $\begin{array}{l}\text { Baroni [3], } \\
\text { Neubauer [12], } \\
\text { Bruns [11], } \\
\text { Jawadi [5], } \\
\text { Deepak [14], } \\
\text { Hong [6], } \\
\text { Saulsburg [7], } \\
\text { Jha [9], Maric [15], } \\
\text { Nizam [13] }\end{array}$ \\
\hline $\begin{array}{l}\text { Painless swelling } \\
\text { of knee }\end{array}$ & 1 & 5 & $1 \mathrm{M}$ & AS & 2 years & None & Van Emelen [10] \\
\hline Politeal cyst & 1 & 12 & $1 \mathrm{M}$ & $\mathrm{OS}+\mathrm{AS}$ & - & - & Meehan [8] \\
\hline $\begin{array}{l}\text { Foot and ankle } \\
\text { pain and swelling }\end{array}$ & 4 & 3-14 (mean 10.3) & $3 \mathrm{M} 1 \mathrm{~F}$ & OS & 6 month-2 years & None & $\begin{array}{l}\text { Neubauer [12], } \\
\text { Aghasi [24], } \\
\text { Freedman [23], } \\
\text { Kaneko [26] }\end{array}$ \\
\hline $\begin{array}{l}\text { Painless mass of } \\
\text { foot and ankle }\end{array}$ & 3 & 11-12 (mean 11.7) & $\begin{array}{l}1 \mathrm{M} \\
2 \mathrm{~F}\end{array}$ & OS & $1-4$ years & None & $\begin{array}{l}\text { Zambakides [25], } \\
\text { Sofier [21], } \\
\text { Duncan [22] }\end{array}$ \\
\hline Elbow & 1 & 8 & $1 \mathrm{~F}$ & AS & - & - & Hsiu Su [19] \\
\hline $\begin{array}{l}\text { Non tender mass or } \\
\text { swelling of elbow }\end{array}$ & 2 & 6 (mean 6) & $2 F$ & OS & 2 years & None & $\begin{array}{l}\text { Sekiya [18], } \\
\text { Aydingoz [17] }\end{array}$ \\
\hline $\begin{array}{l}\text { Multifocal } \\
\text { involvement }\end{array}$ & 6 & 4.5-7 (mean 5.8) & $\begin{array}{l}1 \mathrm{M} \\
5 \mathrm{~F}\end{array}$ & OS & 6 month- 25 years & 3 cases & $\begin{array}{l}\text { Mukhopadhyay [28], } \\
\text { Tavangar [27], } \\
\text { Vedantam [29], } \\
\text { Zhao [30], } \\
\text { Walls [32], } \\
\text { Leszczynski [31] }\end{array}$ \\
\hline Hip pain & 1 & 7 & $1 \mathrm{~F}$ & $A S+O S$ & - & Not reported & Higuchi [20] \\
\hline $\begin{array}{l}\text { Sacral joint } \\
\text { involvement }\end{array}$ & 1 & 12 & $1 \mathrm{~F}$ & OS & - & - & Kang [20] \\
\hline Hand swelling & 1 & 7 & $1 \mathrm{~F}$ & OS & 7 year & 1 case & Neubauer [12] \\
\hline Average & 3.8 & 8.9 & F/M: 1.6/1 & $\begin{array}{l}\text { OS 69\%, } \\
\text { AS 21.5\%, } \\
\text { OS + AS 7\%, } \\
\text { Injection } 2.5\end{array}$ & 4.9 years & $9.5 \%$ & \\
\hline
\end{tabular}

apen synovectomy

${ }^{\mathrm{b}}$ Arthroscopic synovectomy

cMale

${ }^{\mathrm{d}}$ Female 
prefer open surgery to arthroscopy because of the latter's disadvantages, such as the risk of recurrence and the possibility of portal contamination [3].

The literature reported 3 recurrences in cases in which the large joints were affected in multifocal form, and one recurrence in a case affecting the small hand joints (Table 1). The present case was treated with open synovectomy, lateral release, and a proximal realignment procedure and did not show any signs of recurrence during the 24 months following the treatment.

Radiotherapy and isotopic synoviorthesis have been used in adults for relapse cases or as adjuvant modality, but the use of radiotherapy in children is controversial, due to the possibility of post-irradiation sarcoma and damage to the physis [1-4]. Because PVNS, or tenosynovial giant cell tumor (TGCT), has characteristic cytogenetic abnormalities resulting in the overexpression of colony stimulating factor 1 (CSF1), systemic medication targeting the CSF1/CSF1R axis (imatinib, nilotinib, emactuzumab, and PLX3397) has been proposed in patients with diffuse, relapsed, or multifocal PVNS/TGCT [40]. The results from related studies will need to be confirmed in larger, ideally randomized clinical trials [41].

\section{Conclusion}

Although PVNS is a rare condition in pediatric patients, it can occur with symptoms resembling juvenile idiopathic arthritis, therefore it should be considered in differential diagnosis of any arthritis in children. PVNS in children may cause mechanical symptoms such as patellar dislocation. In these cases, lateral release and a proximal realignment procedure, in addition to synovectomy, can be useful methods of treatment.

\section{Abbreviations}

JIA: Juvenile idiopathic arthritis; MRI: Magnetic resonance imaging;

PVNS: Pigmented villonodular synovitis; VMO: Vastus Medialis Obliquus

\section{Acknowledgments}

The authors wish to express their thanks to all hospital personnel involved in this study.

\section{Funding}

The study was performed without any funding.

\section{Availability of data and materials}

Please contact author for data requests.

\section{Authors' contributions}

MK designed the study and carried out the surgery for the patient. MS participated in data collection and wrote the article. RS carried out the rheumatologic consultation and reviewed articles on the subject. All authors read and approved the final manuscript.

\section{Ethics approval and Consent to participate}

Ethic committee approval has been obtained from the ethics committee of Shahid Beheshti University of Medical Sciences and Health Services.

\section{Consent for publication}

Consent to publish the manuscript has been obtained from the patient.

\section{Competing interests}

The authors declare that they have no competing interests.

\section{Publisher's Note}

Springer Nature remains neutral with regard to jurisdictional claims in published maps and institutional affiliations.

Received: 3 January 2018 Accepted: 5 January 2018

Published online: 17 January 2018

\section{References}

1. Ottaviani S, Aryal X, Dougados M, Gossec L. Pigmented villonodular synovitis: a retrospective single center study of 122 cases and review of literature. Semin Arthritis Rheum. 2011:40(6):539-46.

2. Rydholm U. How I do it pigmented villonodular synovitis. Acta Orthop Scand. 1998;69(2):203-10.

3. Baroni E, Russo BD, Masquijo JJ, Bassini O, Miscione H. Pigmented villonodular synovitis of the knee in skeletally immature patients. J Child Orthop. 2010;4(2):123-7.

4. Flandry F, Hughston JC. Current concepts review: pigmented villonodular synovitis. J Bone Joint Surg Am. 1987;69:942-9.

5. Jawadi AH. Pigmented villonodular synovitis of the knee in a 12-month-old girl. J Taibah Univer Med Sci. 2014;9(4):335-7.

6. Man Hong C, TunHing L. Acute knee pain in a child due to pigmented Villonodular Synovitis. J Orthop Case Rep. 2015:5(3):78-80.

7. Saulsbury FT. Pigmented villonodular synovitis of the knee in a 9-year-old child. South Med J. 2004;97(1):80-2.

8. Meehan PL, Daftari T. Pigmented villonodular synovitis presenting as a popliteal cyst in a child. A case report. J Bone Joint Surg. 1994;76(4):593-5.

9. Jha SC, Nishisho T, Matsuura T, Takeuchi M, Miyagi R, Takao S, et al. Pigmented villonodular synovitis of the knee joint in a 5 -year-old girl treated with combined open and arthroscopic surgery: a case report. J Ped Orthop. 2016;25(6):564-9.

10. Van Emelen $\mathrm{K}$, Moens $\mathrm{P}$, Wouters $\mathrm{K}$, Fabry G. Villonodular synovitis of the knee in a 5-year-old child. Apropos of a case. Rev Chir Orthop Reparatrice Appar Mot. 1999:85(6):621-6.

11. Bruns J, Schubert T, Eggers-Stroeder G. Pigmented villonodular synovitis in children. A case report. Arch Orthop Trauma Surg. 1993;112:148-51.

12. Neubauer P, Weber K, Miller NH, McCarthy EF. Pigmented Villonodular Synovitis in children: a report of six cases and review of the literature. lowa Orthop J. 2007:27:90-4.

13. Shand N, Hordon LD. Diffuse pigmented villonodular synovitis in a child - what is the best management? BMC Musculoskelet Disord. 2013;14(Suppl 1):A6.

14. Deepak S, Warrier K, Kerslake R, Rangaraj S. Knee swelling in a teenager infection, inflammation or malignancy? Int J Clin Med Imaging. 2016;3:482.

15. Maric D, Vokovic N, Gajdobranski D, Draskovic B, Bekic V, Jovanovic M, et al. Pigmented villonodular synovitis of the knee in a child - case report. Arch of Oncol. 2004;12(1):75-7.

16. Higuchi C, Ohno I, Yoshikawa H. Hip joint pigmented villonodular synovitis in a young girl: a case report. J Ped Ortho B. 2012;21 (4):335-8.

17. Aydingöz U, Leblebicioglu G, Gedikoglu G, Atay OA. Pigmented villonodular synovitis of the elbow in a 6-year-old girl. J Shoulder Elb Surg. 2002;11(3): 274-7.

18. Sekiya H, Ozawa H, Sugimoto N, Kariya Y, Hoshino Y. Pigmented villonodular synovitis of the elbow in a 6- years- girl: a case report. J Orthop Surg. 2007;15(1):106-8.

19. Su H, Gould E, Penna J, Meng H. A rare manifestation of pigmented Villonodular Synovitis of the elbow in a child. Radiol Case Rep. 2008:3(2):156

20. Kang GH, Chi JG, Choi IH. Pigmented villonodular synovitis in the sacral joint with extensive bone destruction in a child. Pediatr Pathol. 1992;12(5): $725-30$.

21. Soifer T, Guirguis S, Vigorita VJ, Bryk E. Pigmented villonodular synovitis in a child. J Ped Surg. 1993;28(12):1597-600

22. Duncan N, Rajan R. Case report of pigmented villonodular synovitis arising from the calcaneocuboid joint in a 12 year old male. Foot. 2015;25:59-61.

23. Freedman BA, Lin DL, Tis JE. Pigmented Villonodular Synovitis of the Calcaneocuboid joint in an 11-year-old child with Subtalar coalition. Foot Ankle Int. 2007;28(4):511-5.

24. Aghasi MK, Robinson D, Reif RM, Halperin N. Pigmented Villonodular Synovitis of the talus in a child. Foot Ankle. 1988;9(3):139-42. 
25. Christos Z, Stavros C, Vasileios S, Lampros MG, Panagiota G, et al. Pigmented Villonodular Synovitis emerging from the calcaneocuboid joint in a 12-yearold female child: a case report and review of the literature. Orthop Rheumatol. 2016;4(2):555-632.

26. Kaneko K, Nakahara D, Tobe M, Iwase H, Inoue Y, et al. Pigmented villonodular synovitis of the ankle in an adolescent. Intern Orthop (SICOT). 2000;24:234-7.

27. Tavangar SM, Ghafouri M. Multifocal pigmented villonodular synovitis in a child. Singap Med J. 2005;46(4):193.

28. Mukhopadhyay K, Smith M, Hughes PM. Multifocal PVNS in a child followed over 25 years. Skelet Radiol. 2006;35(7):539-42.

29. Vedantam R, Strecker W, Schoenecker P, Salinas-Madrigal L. Polyarticular pigmented Villonodular Synovitis in a child. Clinical Ortho Related Res. 1998; 348:208.

30. Zhao L, Zhou K, Hua Y, Li Y, Mu D. Multifocal pigmented villonodular synovitis in a child: a case report. Medicine. 2016;95(33):e4572.

31. Leszczynski J, Huckell JR, Percy JS, LeRiche JC, Lentle BC. Pigmented villonodular synovitis in multiple joints. Occurrence in a child with cavernous haemangioma of lip and pulmonary stenosis. Ann Rheum Dis. 1975;34(3):269-72.

32. Walls J, Nogi J. Multifocal pigmented Villonodular Synovitis in a child. J Ped Orthop. 1985:5(2):229-31.

33. Myers BW, Masi AT, Feigenbaum SL. Pigmented villonodular synovitis and tenosynovitis: a clinical epidemiologic study of 166 cases and literature review. Medicine. 1980;59:223-38.

34. Xie GP, Jiang N, Liang CX, Zeng JC, Chen ZY, Xu Q, et al. Pigmented villonodular synovitis: a retrospective multicenter study of 237 cases. PLoS One. 2015;10(3):e0121451.

35. Flandry FC, Jacobson KE, Andrews JR. Localized pigmented villonodularsynovitis of the knee mimicking meniscal injury. Arthroscopy. 1986;2:217-21.

36. Özalay M, Tandogan RN, Akpınar S, Cesur N, Hersekli MA, Özkoç G, Uysal M. Arthroscopic treatment of solitary benign intra-articular lesions of the knee that cause mechanical symptoms. Arthroscopy. 2005;21(1):12-8.

37. Delcogliano A, Galli M, Menghi A, Belli P. Localized pigmented Villonodular Synovitis of the knee: report of two cases of fat pad involvement. Arthroscopy. 1998;14(5):527-31.

38. Edwards MR, Tibrewal S. Patello-femoral joint pain due to unusual location of localized pigmented villonodular synovitis: a case report. Knee. 2004;11:327-9.

39. Bartlett MJ, Lavelle J. Localized pigmented villonodular synovitis presenting as recurrent dislocation of the patella. Arthroscopy. 2000;16(7):767-9.

40. Temple HT. Pigmented villonodular synovitis therapy with MSCFinhibitors. Curr Opin Oncol. 2012;24(4):404-8.

41. Brahmi M, Vinceneux $A$, Cassier PA. Current systemic treatment options for tenosynovial giant cell tumor/pigmented villonodular synovitis: targeting the CSF1/CSF1R axis. Curr Treat Options in Oncol. 2016;17(2):10.

\section{Submit your next manuscript to BioMed Central and we will help you at every step:}

- We accept pre-submission inquiries

- Our selector tool helps you to find the most relevant journal

- We provide round the clock customer support

- Convenient online submission

- Thorough peer review

- Inclusion in PubMed and all major indexing services

- Maximum visibility for your research

Submit your manuscript at www.biomedcentral.com/submit 